\title{
EXPLORING VALUES AND ATTITUDES TOWARDS CSR AMONGST CEMS SGH STUDENTS IN POLAND
}

\begin{abstract}
The objective of the paper is to explore the values and attitudes of CSR amongst CEMS SGH students in Poland. CEMS - the global alliance of management education is an association of best universities around the world. There are 29 prominent partner universities, amongst others are: Warsaw School of Economics in Poland, University of Economics in Czech Republic or ESADE in Spain. Students are perceived as future managers of the corporate world and their perception about CSR is deemed important to business organisations. The education sector is seen as playing a crucial role in preparing the next generations of future leaders through incorporating CSR related subjects into programmes and research. The study will offer a unique insight into the CSR attitudes of business students in a job choice context answering the question in which extent CEMS education shapes the values of students. The research was undertaken using online survey. CSR values were explored in the context of a hypothetical job search scenario. While the majority of students rated CSR values highly in the job choice scenario, a larger majority were willing to trade this off for greater extrinsic benefits. The results of the research will permit to design effective business programmes that shape the social responsibility behaviours of the next generation of managers and leaders. This paper used survey data from small sample of management students in a limited geographic area that is Poland. Hence, it might be difficult to generalize the results to a larger, more representative population.

Keywords: Corporate social Responsibility, CEMS education, business education, values, attitudes to corporate social responsibility
\end{abstract}

\section{INTRODUCTION}

Over the past decade and especially since the global financial crisis beginning in 2008 there has been an increasingly vocal debate inside the world's 13,000 business schools and related stakeholders in companies and elsewhere, about whether management education is fit for purpose, triggering conversations among business educators and the business press, asking "Just what are they teaching in business schools?"2.

In order to counter this unhealthy phenomenon, many business schools and academic scholars call for reinforcement of the concept of corporate social responsibilities (CSR) in their programs and curriculum in order to shape and instil such values in the people that will lead the corporations tomorrow ${ }^{3}$. The question is no longer whether CSR should have a place in the business curricula, but how it should be incorporated, and, perhaps more importantly, what role business schools have to play in CSR education.

\footnotetext{
${ }^{1}$ Dr Celina Sołek-Borowska, Instytut Zarządzania, Kolegium Zarządzania i Finansów, Szkoła Głowna Handlowa w Warszawie, ul. Madalińskiego 31/33, 02-554 Warszawa, e-mail:csolek@sgh.waw.pl

${ }^{2}$ M. Gentile, Business schools: a failing grade on ethics, "Business Week" 2009, 5 February, available at: www.businessweek.com/bschools/content/feb2009/bs2009025_129477.htm (accessed 25 January 2010).

${ }^{3}$ J. Bartunek, Corporate scandals: how should Academy of Management members respond?, "Academy of Management Executive" 2002, Vol. 16, p. 138.
} 
Worldwide, organizations are increasingly expected to behave in ethically and socially responsible ways and their leaders to possess the competencies and skills to address a range of issues including equity, sustainability and ethics ${ }^{4}$.

Universities should prepare students to enter the labour market so that graduates can forecast and react to changes that may occur in the future economy. The scope of university education should embrace the global scope of companies. Simultaneously, universities ${ }^{5}$ should play an active role in disseminating good citizenship, creating the conditions for the development of free economy and development of good relations with the stakeholders ${ }^{6}$.

Organizations that will be employing management graduates increasingly demand them to "hit the ground running". Van Baalen and Moratis ${ }^{7}$ have addressed the issue of relevance from the perspective of the role of business schools emerging network economy. They contend: "The management curriculum itself has been a focus of corporate criticism over the years, being accused of being developed on the basis of a view that has been characterized as being too internally oriented. Business schools, many corporate executives will contend, should have a keen eye for what happens outside its walls and try to bridge the dicrepancies of what they offer and the corporate sector really needs. Existing perceived curricular deficiencies have to be overcome, which, perhaps, can be realized best by developing close intellectual partnerships with the business sector. The main challenge business schools are being posed with considering the business school curriculum entails developing curricula and educating managers in order to prepare managers for the network economy".

While the turbulent international business environment challenges business executives to rethink existing managerial models, Garcia and Dolan ${ }^{8}$, Dolan and Richley ${ }^{9}$, Dolan et al. ${ }^{10}$ developed an original framework emphasizing the importance of the underlying values structure, and asserting that it is essential for today's managers, to replace earlier philosophies such as "Management by Instruction" and "Management by Objective". Dolan and his colleagues propose that "Management by Values" is the emerging strategic leadership tool of significant potential for practical applications to resolve the problems facing the 21 st century organizations. Thus, managers' values represent a predisposition to behave; the chain leading from attitudes to behaviour is direct and is explicit in the work context.

\footnotetext{
${ }^{4} \mathrm{H}$. Pesonen, Challenges of integrating environmental sustainability issues into business school curriculum: a case study from the university of Jyva skyla, Finland, "Journal of Management Education" 2003, Vol. 27, No. 2; S. Young, S. Nagpal, Meeting the growing demand for sustainability-focused management education: a case study of a PRME academic institution, "Higher Education Research \& Development" 2013, Vol. 32, No. 3.

${ }^{5}$ For the purpose of this paper the university or higher education institution are used interchangeably.

${ }^{6}$ M. Geryk, Społeczna odpowiedzialność uczelni, Szkoła Główna Handlowa w Warszawie, Warszawa 2012.

${ }^{7}$ P.J. Van Baalen, L.T. Moratis, Management Education in the Network Economy: Its Context, Content, and Organization, Kluwer Academic Publishers, Dordrecht 2001.

${ }^{8}$ S. Garcia and S.L. Dolan, La direccio ' $n$ por valores, McGraw-Hill, Madrid 2003.

${ }^{9}$ S.L. Dolan, B. Richley, Management by values (MBV): a new philosophy to absorb the complexity of managing organization in a new economic order [in:] Handbook of Business Strategy, ed. P. Coats, 2005.

${ }^{10}$ S.L. Dolan, S. Garcia, B. Richley, Managing by Values: A Corporate Guide to Living, being Alive and Making a Living in the 21st Century", Palgrave-Macmillan, London 2006
} 
CSR has been an increasingly important area of focus in both academia and in practice. As an example, Christensen et al. ${ }^{11}$ found that 42 percent of the top global MBA programs require CSR as part of their core content. Many higher learning institutions conduct CSR activities for the benefit of their stakeholders - including administrators, lecturers, staff, and students - together with the community. Universities are known as places in which students can gain knowledge and experience, and are platforms to promote beneficial and healthy lifestyles to students, including exposure to and practice of good $\mathrm{CSR}^{12}$. As the corporate world debates the merits of corporate sustainability specialists versus mainstream generalists, there is a growing need for business educators to grasp this issue by the horns. To date, with a few exceptions, business education at European level and international level has failed to answer the debate in a coherent way.

Higher education institutions are argued to play a pivotal role in global sustainable development: "No institutions in modern society are better situated and none more obliged to facilitate the transition to a sustainable future than colleges and universities"13. This pressure on business schools to transform themselves is being met with a variety of responses. These include a growing number of courses and seminars, in-house consulting, new academic research and teaching networks and a plethora of tools. Moreover more and more universities make close links with foreign universities to deliver world class education. On the other hand business schools have been accused of assisting to create "the end of the business world as we know it" with calls for a greater emphasis on ethics ("The Economics" 2009). A report on business schools curricula "post downturn" by Durham Business School (2009) acknowledged that business schools were widely criticized for contributing to the current economic crisis by producing MBAs that "are focused on creating shareholder value and high risk strategies instead of sustainable practices and stakeholder responsibility". For Haniffa ${ }^{14}$ : "Business school faculty can have the greatest impact on the way the next generation of corporate leaders think, which will be more effective than any legislation. They need to be role models who can inspire and challenge current business models. We have to move away from teaching business as a science devoid of moral or ethical considerations, as that results in managers who lack personal reflection and values".

Critics say that these remedies attempting to educate future managers comes too late, but other believe that it might minimize future ethically based risks, all depending on the set of values the future managers enter the world of work after graduation.

\section{IMPORTANCE OF CSR EDUCATION - LITERATURE REVIEW}

Despite differences of opinion about the efficacy of CSR, there is a general consensus among academics, policy makers, and practitioners that corporations operate with a social

\footnotetext{
${ }^{11}$ L.J. Christensen, E. Pierce, L.P. Hartman, W.M. Hoffman, J. Carrier, Ethics, CSR, and sustainability education in the Financial Times top 50 global business schools: baseline data and future research directions, "Journal of Business Ethics" 2007, Vol. 73 No. 4.

${ }^{12}$ C. Nicolescu, Corporate Social Responsibility in the Romanian Higher Education, Open Society Institute, Romania 2006.

${ }^{13}$ D. Orr, The Nature of Design, Oxford University Press, New York 2002.

${ }^{14}$ R. Haniffa, Ethics are needed in the boardroom, "Financial Times" 2009, November 29, available at: www.ft.com/cms/s/4230ad3e-db4f-11de-9023-00144feabdc0.html (accessed 25 January 2010).
} 
sanction that requires that they operate within the norms and mores of the societies in which they exist ${ }^{15}$.

Management education needs to keep up with current and anticipate future developments and align its curriculum to the best extent possible with the demands of business while at the same recognizing its objective to educate students in a culture of liberal education. A prominent recent turn in the challenge of relevance pertains to a profound development in the world of business: the increased attention for corporate social responsibility (CSR).

CSR increasingly receives attention from managers and researchers. However, most of this research was conducted in the context of developed countries, which are prominent in their CSR activities. Compared with the growing body of literature on the nature of and consequences of CSR, however, the matter of how to improve the companies' level of CSR has received relatively limited attention. Nonetheless, CSR research in the recent past has primarily focused on identifying the ideal "how to carry out CSR". Scholars have paid considerable attention in studying the relationship between CSR and firm performance. Yet, little empirical research demonstrates how can education sector can shape values and attitudes of business students.

Clearly, with increasing public exposure, corporate social responsibility is building a more solid platform in the public's awareness, but at the same time there is a common struggle between the wish to be socially responsible and the competing pressures of business performances. What is important to note, however, is that there is escalating evidence from academic studies that shows "positive correlations between responsible business behaviour and return-on-investment, stock price, consumer preferences and employee loyalty"16.

Business schools may play an important role, both by developing business-oriented research on the concept and the implementation of CSR and by mainstreaming them in their different training and education programmes. Academic institutions are in a position to provide today's and tomorrow's managers with knowledge about the positive impact of a CSR strategy on companies' long-term performance and about the tools and procedures that characterize a sound and integrated CSR approach.

This is confirmed by Kolondinsky et al. ${ }^{17}$, Persons ${ }^{18}$ who ascertain that the education sector is seen as playing a critical role in preparing the next generation of leaders both through research into CSR and by incorporating CSR-related subjects into their education and training programs.

Business schools have a duty to give students a solid grounding in the theory underpinning the role of sustainability as a preparation for the real world situations they will ultimately encounter. Universities recognize that teachers of core courses like - such as finance, strategic management, marketing and accounting - need to know where sustainability issues affect their own module content and how to teach this relationship.

\footnotetext{
${ }^{15}$ P. Jain, S.K. Datta, A. Roy, Awareness and attitude towards corporate social responsibility, "International Journal of Law and Management" 2014, Vol. 56, Iss. 3, http://dx.doi.org/10.1108/IJLMA-05-2012-0012.

${ }^{16}$ B.N. Kumar and H. Steinmann (Eds), Ethics in International Management, de Gruyter, New York 1998.

${ }^{17}$ R.W. Kolondinsky, T.M. Madden, D.S. Zisk and E.T. Henkel, Attitudes about corporate social responsibility: business student predictors, "Journal of Business Ethics" 2010, (91).

${ }^{18}$ O. Persons, Incorporating Corporate Social Responsibility and Sustainability Into a Business Course: A Shared Experience, „Journal of Education for Business“ 2012, (87).
} 
Therefore CSR education is considered important for a number of reasons.

1. Firstly, as noted, it is seen as indispensable for the development of a new generation of socially responsible leaders ${ }^{19}$.

2. Secondly, it is becoming increasingly important in professional (e.g. accounting) and educational accreditation (e.g. Association to Advance Collegiate Schools of Business) ${ }^{20}$.

3. Thirdly, effective CSR strategies are increasingly recognized as good business practice $^{21}$.

4. Lastly, sensitizing students to CSR issues should assist them in the job search process by enabling them to more accurately discriminate between the genuine CSR credentials and "spin" signalled by potential employers ${ }^{22}$.

However, while much has been written about the need for CSR education, particularly in postgraduate programs, far less attention has been paid to exploring the CSR values and attitudes of students at the undergraduate level ${ }^{23}$. Yet knowledge of these, particularly for educational institutions is important for at least two reasons. First, curricula which content and delivery acknowledges and incorporates students' views and opinions increases their relevance and meaning ${ }^{24}$, which ultimately should increase the ability of courses to address the social responsibility demands of organizations and the broader society. This is particularly important for subjects that are grounded in concepts such as values, sustainability and moral obligation typical of those offered in the suite that comprises CSR education.

Second, at the classroom level knowing about students' CSR views and attitudes should enhance educators' ability to frame the discourse in ways that students can relate to and engage in. Business education in particular has long been criticized for being overly procedural, organization-centric and geared towards the ethics of personal advantage ${ }^{25}$. Moreover, given the global increase in awareness of environmental and social responsibility issues, it is worth to investigate the possible values and attitudes to CSR.

Therefore, the aim of this paper is to explore the CSR values of current SGH CEMS (Global Alliance in Management Education) students. The students which have been selected are coming from Warsaw School of Economics (SGH) in Poland. The context selected is that of a hypothetical job scenario. Gauging students' views is seen as an important element in the CSR curriculum development planned for future years. The quality of business education has implications for the relevance of courses offered at the institution concerned and students' job choice decisions, both of which have implications for

\footnotetext{
${ }^{19}$ Ibidem.

${ }^{20}$ M.G. Lamoreaux and P. Bonner, Preparing for the next opportunity, "Journal of Accountancy" 2009, (208) No. 5; O. Persons, op. cit.

${ }^{21}$ I. Ducassy, Does Corporate Social Responsibility Pay Off in Times of Crisis? An Alternate Perspective on the Relationship between Financial and Corporate Social Performance. Corporate Social Responsibility and Environmental Management Corp. Soc. Responsib. Environ. Mgmt 2012.

${ }^{22}$ D. Owen, CSR after Enron: a role for the academic accounting profession?, "European Accounting Review" 2007, (14), No. 2.

${ }^{23}$ R.W. Kolondinsky, T.M. Madden, D.S. Zisk and E.T. Henkel, op. cit.

${ }^{24}$ M. Prosser \& K. Triggler, Understanding Learning and Teaching. The experience in higher education, University Press ed., Milton Keynes 1999.

${ }^{25}$ D. Owen, op. cit.; R.W. Kolondinsky, T.M. Madden, D.S. Zisk, and E.T. Henkel, op. cit.
} 
future directions of work practice. The key dimensions of this investigation and their justification are discussed in the following section.

Understanding dimensions of students' CSR perceptions is an important first stage in educating the next generation of employees/leaders to be both socially responsible and astute in the job choice process. Changes in the broader society and possible changes in generational preferences suggest that research into students' CSR work values and attitudes needs to be ongoing. As part of this, the study described here addresses the following research questions:

RQ1. Is organizational CSR an important criterion in the job choice process among CEMS SGH students in Poland?

RQ2. What decisions is going to be made by CEMS SGH graduate concerning the company which offers great career opportunities but is very little engaged in CSR?

RQ3. What are students' value priorities among key CSR dimensions?

This paper has as its focus a small-scale study comprising of 45 CEMS SGH (Warsaw School of Economics in Poland). The questionnaire was tested first within CEMS CLUB Warsaw to assess whether the questions were clear and easily understood. The research commenced on 10th May 2015 and was completed on $1^{\text {st }}$ December 2015 using electronic survey. The link to the questionnaire was placed on Facebook CEMS SGH groups. Additionally the questionnaire was sent to current students and alumni of CEMS in Poland using regular email. The questionnaire altogether was sent to 200 students. As it was an online survey the respondents had a chance to post their comments online. The questionnaire was well received. Students were sharing their positive experiences regarding taking part in CSR projects whilst studying.

In the survey the majority of students and graduates were aged (18-25). The sample was nearly equal considering the participation of female (46,67 per) and men $(53,33 \%)$.

\section{GLOBAL ALLIANCE IN MANAGEMENT EDUCATION (CEMS)- MAIN IDE- AS AND ASSUMPTIONS}

CEMS is the network of best universities and corporate partners that offer joint Master programme on Management on the higher international level. Internalization of the higher education sector forces structural changes in universities all over the world. Along with an increasing number of students participating in students' exchange there is a growing search for new models of business education, a growing presssure for making changes or implementing certain patterns.

This is one of the reason why universities partner with the others but it is also followed by the increasing competition for home-based and overseas students and higher educational institutions now recognise that they need to market themselves in a climate of international competition. The flag product of CEMS is Master in International Management (MIM). This one-year joint degree programme is exclusively open to the Master's students of the CEMS schools who meet very strict selection criteria, and receive the CEMS degree in conjunction with their home degree. CEMS also fosters faculty cooperation for joint teaching, research and doctoral education. The CEMS-MIM was intended to provide students with an opportunity to commute between the various countries and partner schools, thus widening their national horizons (Fig. 1). 
Fig. 1. Structure of CEMS MIM programme
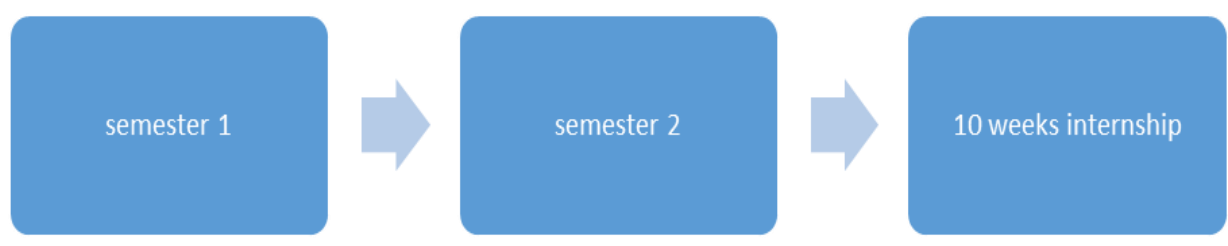

Source: Own development.

The mission of the organization is formed as such: "CEMS is a global alliance of academic and corporate institutions dedicated to educating and preparing future generations of global business leaders to enter into a multilingual, multicultural and interconnected business world through the CEMS Master's in International Management"26.

The partnership between companies and universities is a unique feature of the CEMS organisation, giving room to an enormous potential of networking and international cooperation. The partnership materialises in the joint development and teaching of the CEMS MIM, which represents both a platform for academics and practitioners for knowledge creating cooperation in the field of Management and a unique learning opportunity for students by giving them access to innovative course content, relevant international exposure and applied project work ${ }^{27}$. Since late-2010, CEMS has welcomed NGOs and inter-governmental organisations into the alliance to stimulate positive change in international management and to broaden students' views to foster critical thinking. CEMS commitment to an ethical and responsible approach to management education includes a strong focus on sustainability. Through the involvement of social partners in the classroom and governance, to faculty groups and students working on corporate social responsibility and sustainability issues, all CEMS stakeholders benefit from this global discussion on sustainability.

The CEMS MIM learning objectives are its core attributes that constitute the programme's specific, competitive positioning are such as:

\section{1/ Internationalism}

Our graduates are knowledgeable international business practitioners, able to execute effective business decision-making and change management in diverse contexts.

\section{2/ Practical Approach}

\footnotetext{
${ }^{26}$ www.cems.org (retrived: February 10, 2015).

${ }^{27}$ University Guideline for the CEMS Master's in International Management, internal CEMS materials.
} 
Our graduates apply advanced management and leadership competencies developed through systematic experience of and engagement with the corporate world.

3/ Responsible Citizenship

Our graduates champion a holistic vision of responsible business decision-making, leadership and citizenship, informed by ethical reasoning, personal integrity, and respect for social diversity.

4/ Reflective Critical Thinking

Our graduates are confident, agile, and reflective decision-makers and problemsolvers, able to formulate and apply innovative solutions to complex business challenges.

5/ Comprehensive Leadership

Our graduates are fully aware of their personal responsibility and accountability and of the ethical and cultural frameworks in which leadership is exerted ${ }^{28}$.

CEMS network is a response to the complexity of managing in today's economic landscape at the same time because of the level of development of management science, it is necessary to offer the curriculum drawing on the experience of the best universities and companies in the world. One university hasn't got the most talented professors. In the globalized world the knowledge has to be gathered from universities worldwide, companies and non-profit organization alike. Only constant observation of the business world can prepare future leaders to face incoming challenges.

The CEMS Courses, which integrate corporate and academic expertise in the discussion of international business scenarios with students, are mainly taught in the programme's first semester; whereas the second semester is leading students to more independent learning activities: in a consulting-like team driven Business Project, and in writing an international research paper. Multicultural aptitude and multilingual skills excellence in written and oral English being a must - an internship abroad and Skills Seminars aim at completing the CEMS graduates profile: fit for starting a career and assuming responsibility in the fast changing environment of global management tasks ${ }^{29}$.

Skill Seminars are training seminars in practical skills relevant to an international management environment. The topics may include:

- Time management,

- Intercultural skills,

- Moderation techniques,

- Group work abilities,

- International negotiation,

- Presentation skills.

Small groups of students (10-15 students) ensure an interactive dimension. Skill Seminars are not graded. The emphasis is on training, not on assessment of the performance. Skill Seminars are offered within CEMS programme, very often in close cooperation with companies. In case of SGH, CEMS students for the cohort 2015/2016 are taking part in the obligatory skill seminar titled: Responsible Global Leadership. Participation in the skill seminar is obligatory and essential for students to start an effective professional career and adjust easily to an international management

\footnotetext{
${ }^{28}$ www.cems.org (retrived: February 10, 2015).

${ }^{29}$ University Guideline for the CEMS Master's in International Management, internal CEMS materials.
} 
environment. The core module obligatory for all the students is: Corporate Governance which is based on case study analysis.

The combination of two worlds: the companies and universities from around the world, it is essential today, when the various disciplines of science and technology have developed their own code of conduct and the globalization of knowledge and modern technology have long since entered the walls of the university. In the knowledge -based economy, two actors, i.e. businesses and universities, they seem to be preoccupied to close cooperation. These two partners who have different missions and objectives, have a chance to solve the current economic, social, religious dilemmas. The young graduate equipped with an arsenal of knowledge, ideas, will be challenged to pass it on, to serve businesses, the state with their skills, knowledge. In today's globalized world, universities are becoming the mainstay of knowledge and guarantee of its sharing.

\section{RESULTS AND DISCUSSIONS}

As a current student or graduate, the needs of job seeker largely concern judging whether or not a particular organization would be a good place to work ${ }^{30}$. A number of empirical studies support the significance of CSR activity on these judgements, finding that perceptions of positive CSR performance enhance organizational attractiveness and subsequent job pursuit intentions ${ }^{31}$. It has been found that CSR education enables students to better evaluate the CSR credentials of potential employers ${ }^{32}$.

It was not surprising that $75,56 \%$ of CEMS SGH students think that organization commitment towards CSR should be visible through environmental, ethical human rights and consumer concerns into every day in their business operations. But every fourth student thinks that CSR is of a second importance as the main obligation for a company is to make profit. SGH students are very much performace oriented and the main specialization that students enrol at bachelor level is Finance and Accounting. Moreover students are aware that after completing such degree they will have not a problem to find a job after graduation. Close links with the business may possible for the best students to be spotted by the potential emplyoer. It may the case where a teacher becomes a boss.

CSR rating is an important factor to consider when applying for a job.

The responses to the question: how important is the business education in shaping CSR values and attitudes is presented on the Fig. 2

\footnotetext{
${ }^{30}$ H.S. Albinger, S.J. Freeman, Corporate social performance and attractiveness as an employer to different job seeking population, "Journal of Business Ethics" 2000, Vol. 28; K.B. Backhaus, B.B. Stone, K. Heiner, Exploring the relationship between corporate social performance and employer attractiveness, "Business and Society" 2002, Vol. 41, No. 3.

${ }^{31}$ T.S. Behrend, B.A. Baker and L.F. Thompson, Effects of pro-environmental recruiting messages: the role of organizational reputation, "Journal of Business Psychology" 2009, Vol. 23; W.R. Evans, and D.D. Davis, An examination of perceived corporate citizenship, job applicant attraction and CSR work role definition, "Business and Society" 2011, Vol. 50 No. 3.

${ }^{32}$ D. Owen, op. cit.; W.R. Evans, D.D. Davis, op. cit.
} 
Fig. 2. Importance of business education in shaping SGH student attitudes towards CSR

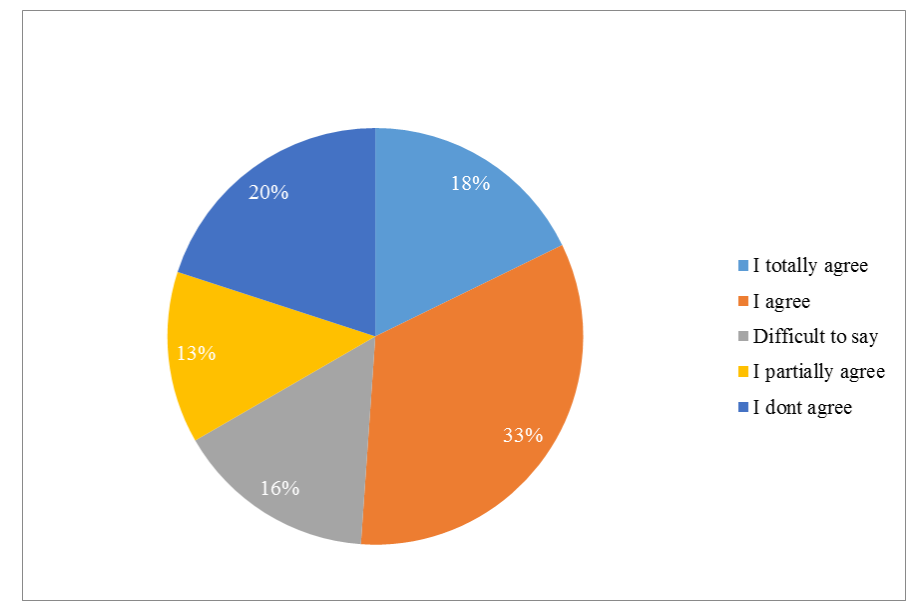

Source: Own development.

Students of CEMS SGH were certain on importance of business education. $18 \%$ totally agree with that statement. $50 \%$ of students assume that my business education influenced the way they think of CSR. To test the statistical hypothesis, the zero and alternative hypothesis were tested with the use of $\chi^{2}$ statistics. The $\mathrm{H}_{0}$ and $\mathrm{H}_{1}$ hypothesis can be formulated as follows: sible

$\mathrm{H}_{0}=$ the classes I have participated in did not influence me to be more socially respon-

$\mathrm{H}_{1}$ the classes I have participated in influenced me to be more socially responsible $\chi^{2}=17,12$ when $\mathrm{p}=9,48$, and $\alpha=0,05$

Therefore the $\mathrm{H}_{0}$ is rejected for the benefit of $\mathrm{H}_{1}$ hypothesis. This confirms that the business education in both universities shapes the attitudes of the students which is consistent with Kolodinsky ${ }^{33}$. This is a signal for educators of the importance of CSR subjects that should be incorporated within the business curricula. Students working on real life examples can perceive the value and importance of CSR that should be built within each area of business operation.

The next question: "If a company provided outstanding career opportunities/travel opportunities/salary and rewards but engaged very little in CSR, I would NOT consider applying to such a company" was designed not only to validate the previous item, but also to evaluate whether students' view on the importance of CSR would waver if faced with a situation that entailed trade-offs. The division of answers in visible on Fig. 3.

\footnotetext{
${ }^{33}$ R.W. Kolondinsky, T.M. Madden, D.S. Zisk and E.T. Henkel, op. cit.
} 
Fig. 3. Business opportunities but little engagement in CSR

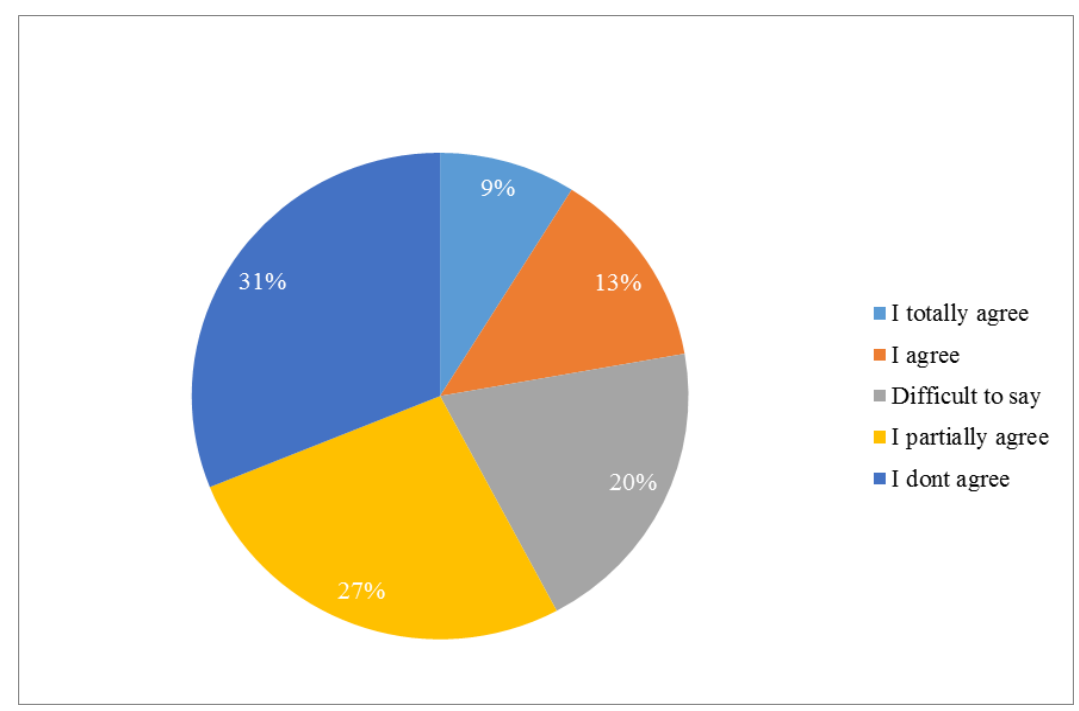

Source: Own development.

With respect to proposition two, the hypothetical CSR-rewards trade-off option, over half the sample (58 per cent) reported that they would consider applying to an organization that offered outstanding rewards but engaged little in CSR, 22 per cent maintained their CSR value stance by agreeing with the proposition and 20 per cent were undecided. The distribution of answers is interesting considering the average grade and gender. Every fourth student with a high average grade (4.5-5.0) would not consider applying to such company. This confirm the value of god marks. Are they a condition for obtaining a wellpaid job and the possibility to choose amongst alternative job offers? It may be the reason. The response rate considering gender is not significant 23,81 per cent of female would not accept such offer and 20,84 per cent of men respectively. The difference between the means (utilizing the full five-point Likert scale) for the two propositions was statistically significant.

$\mathrm{H}_{\mathrm{o}}=$ the student will not consider applying to a company which engaged very little in CSR even though it provided outstanding career opportunities

$\mathrm{H}_{1}=$ the student will consider applying to a company which engaged very little in CSR even though it provided outstanding career opportunities

$\chi^{2}=17,78$ when $p=9,48$, and $\alpha=0,05$ SGH CEMS

Therefore the $\mathrm{H}_{0}$ hypothesis is rejected for the benefit of $\mathrm{H}_{1}$ hypothesis.

The students would apply to a company which is very little engaged in CSR but offers outstanding career opportunities. On such basis it can be concluded that although SGH students have a positive attitude towards CSR when challenged with job prospects they 
would not drop a great chance of potential job when a company is very little engaged in CSR. That pecuniary rewards would seem to sway the social conscience of a majority of students, however, is consistent with much of the research on new generation suggesting a tendency to be motivated more by economic rewards and start salaries than other generations. This can explained as well by the situation that for young generation it is becoming more and more difficult to obtain a well-paid job. Great education is just a gate to the business world not a guarantee. Moreover when applying for a first job it is expected from students that during their time at the university apart from studying they were involved in different student initiatives or were part of student's association. Since SGH has got prominent links with the business, the quest for excellent students is always in search. Even though SGH is ranked as the best business school in Poland we would expect students to be more socially astute knowing their privilege of being a graduate from a well-known business school in Poland. Another explanation can be offered saying that CSR module has just been recently incorporated into curriculum in business schools (roughly 10-15 years ago)

To assess perceptions of the relative importance of five CSR dimensions respondents were asked to rank each using a scale from 1 ("most important") to 5 "(least important"). Four of the dimensions and their descriptions were drawn from the RepuTex (2011) Corporate Sustainability Report. These are corporate governance (ethical business conduct, audit and compliance, shareholder relations), workplace practices (workplace relations, occupational health and safety, anti-discrimination measures), social impact (human rights, community investment and development) and environmental impact (pollution, use of unsustainable resources, use of animals for product testing). To explore the market practices dimension further a fifth dimension "fair operating practices" was added.

Table 1 shows the frequencies and rank of the five CSR dimensions explored. It can be seen that in the "most important" column workplace practices ranked first (48,89 per cent) and environmental impact last $(8,89$ per cent). At the opposite end of the spectrum, rated the "least important" were environmental impact and fair operating practices $(35,56$ and 24,44 per cent, respectively). Overall, it appears that when it comes to the question of CSR in the workplace, the students were the most concerned about workplace practices and policies and were the most undecided or negative in about issues of environmental impact.

The relative importance of each dimension has been found to vary according to the stage of the job acquisition process, the job role envisaged, student characteristics and the extent of their CSR education. While initial attraction/job pursuit intentions appear to be mostly influenced by the first three of these dimensions (possibly because they serve as a proxy for the organization's working conditions), the findings for environment appear to be the most diverse.

Table 1. Ranking of CSR initiatives

\begin{tabular}{|l|l|l|l|l|c|}
\hline \multicolumn{1}{|c|}{ CSR dimensions } & $\begin{array}{c}1 \text { (most } \\
\text { important) }\end{array}$ & 2 & 3 & 4 & $\begin{array}{c}5 \\
\text { (least important) }\end{array}$ \\
\hline Workplace practices & $48,89 \%$ & $20,00 \%$ & $17,78 \%$ & $8,89 \%$ & $4,44 \%$ \\
\hline Social impact & $13,33 \%$ & $28,89 \%$ & $20,00 \%$ & $24,44 \%$ & $13,33 \%$ \\
\hline Corporate governance & $11,11 \%$ & $20,00 \%$ & $24,44 \%$ & $22,22 \%$ & $22,22 \%$ \\
\hline Environmental impact & $17,78 \%$ & $8,89 \%$ & $11,11 \%$ & $26,67 \%$ & $35,56 \%$ \\
\hline Fair operating practices & $8,89 \%$ & $22,22 \%$ & $26,67 \%$ & $17,78 \%$ & $24,44 \%$ \\
\hline
\end{tabular}


Source: own development.

Using a hypothetical job choice scenario this study sought to understand SGH CEMS and VSE CEMS students' attitudes towards organizational social responsibility values in an era of heightened sensitivity around human and environmental issues.

Whilst more than half the sample agreed that organizational CSR was important, the hypothetical trade-off posited between higher extrinsic work rewards and lower CSR resulted in a significant reversal of the reported importance of CSR values in the job choice decision. That pecuniary rewards would seem to sway the social conscience of a majority of students, however, is consistent with much of the research suggesting a tendency to be motivated more by economic rewards and start salaries ${ }^{34}$. Referring to the CSR dimensionality analysis, when students were asked to rank the five CSR dimensions, noticeable differences emerged. Workplace practices were rated as the most important social responsibility dimension in this Polish context and environmental impact, corporate governance and climate as the least important. The high ranking given to workplace practices is consistent with the findings of other studies. Concern about workplace practices may be more paramount for the current generation of job seekers, given the stressful and uncertain nature of the contemporary workplace ${ }^{35}$.

Given the conflicts in research findings on work values referred to earlier, the analysis of individual differences demonstrated a striking consistency regarding the influence of gender and average grade during CEMS students on CSR work values. Female students' stronger altruistic values as indicated by their resistance to the financial rewards/CSR trade-off are consistent with patterns identified in other generations ${ }^{36}$ as is the positive correlation identified between CSR importance and average grade. This leads to the conclusion that within the context of CSR values and their drivers, intergenerational differences maybe over-emphasized and that certain within-generation differences are more significant. One important implication is the need for educators to be aware that different student groupings may adopt different paradigms for interpreting CSR issues and may require approaches tailored to their specific needs in learning to apply CSR values in ethical and recruitment decisions. In the broadest of terms females, males and high and low achievers constitute four possible groupings.

Although it was a survey students eagerly shared their experiences in taking part in CSR initiatives. The most popular seemed to be: Polish-Israel dialogue forum or CEMS Chance. Chance CEMS is an innovative project aimed at ambitious and talented pupils of junior high school and upper secondary schools. The initiative aims to help young people make educational decisions and to plan career. It is organized two times per year in the form of conferences and workshops.

\section{CONCLUSION}

This study reinforces the importance of exploring the CSR work values of CEMS SGH students and their priorities among key CSR dimensions to help inform the design of

\footnotetext{
${ }^{34} \mathrm{P}$. Chen, Y. Choi, Generational differences in work values: a study of hospitality management, "International Journal of Contemporary Hospitality Management" 2008, (20), No. 6.

${ }^{35}$ J.M. Twenge, S.M. Campbell, Generational differences in psychological traits and their impact on the workplace, "Journal of Managerial Psychology" 2008, (23).

${ }^{36}$ K.B. Backhaus, B.B. Stone, K. Heiner, op. cit.
} 
curricula that will enhance their social responsibility values and their job choice decisions. Although the majority of students place a high ranking to CSR stating that CSR is an important factor when searching for a job but faced with a reality the answers contradict the previous statement. Students would accept job offer with a company that is barely engaged in CSR. The results may reflect quite high unemployment amongst graduates and therefore simply students may not have the choice. Students at CEMS SGH have a unique opportunity to study practically. Because some modules are run by the managers from different companies and SGH as a business school must make sure that they follow and teach young generations an appropriate approach toward CSR. The current findings represent a starting point for curriculum development, changes in the broader society as well as naturally occurring differences between student cohorts make it advisable also to periodically monitor students' CSR views. The results here have the potential to serve as a valuable benchmark for evaluating the impact of the planned curricula on the CSR values of business students in future years.

Business education is by nature an academic field that deals with very practical situations and must ultimately produce hands-on solutions. Thus corporate sustainability thinking needs to be built into business education in a way that reflects the real issues that students will have to deal with as future managers in everyday strategic decision-making, not just in times of crisis.

Limitation of this study is the relatively small sample size. This is a concern both in terms of external validity and statistical power. First, it is difficult to generalize results from an experiment employing a small student sample to a larger, more representative population. Thus, the robustness of the results from this study needs to be tested in future studies conducted with a larger, more representative sample. Second, a small sample size tends to be associated with a relatively low statistical power.

Additionally, the study did not investigate the reasons underlying the responses, particularly in the case of the "neither agree/disagree" category and the prioritization of "workplace practices" in the dimensionality analysis. Exploring the reasons behind these responses would be fruitful areas of further research. Lastly, as the data are self-reported and drawn from two location the results are limited in their generalizability to other contexts. They may, however, serve as a useful point of comparison with similar studies involving different disciplines.

The results of this research need to be confirmed by further research in several directions. First, the questionnaire might be diffused in other countries with different educational systems in order to confirm the impact of academic institution on the way CSR is perceived considering cultural differences. Second, the questionnaire should be submitted to a group of older managers in order to check whether and to what extent the impact of the academic institution is confirmed after several years of experience as managers.

The results of this study have provided some valuable insights that can be used to inform the design of an effective business program as part of one institution's efforts to shape the social responsibility and job choice behaviours of the next generation of managers and leaders.

The increasing awareness of CSR in the society calls for systematic research that could potentially provide managerial guidance for corporate decision makers and organization leaders. The phenomenon of CSR ensures long-term sustainability and new horizons for the corporate houses and on the other hand, poses thought-provoking research questions; in and of itself, it is a fascinating topic for academic endeavors. One more time the author 
would like to highlight that business schools are in a unique position, placed between student and employers, to lead in exploring corporate social responsibility issues.

\section{REFERENCES}

[1] Albinger H.S., Freeman S.J., Corporate social performance and attractiveness as an employer to different job seeking population, "Journal of Business Ethics" 2000, Vol. 28, pp. 243-253.

[2] Backhaus K.B., Stone B.B., Heiner K., Exploring the relationship between corporate social performance and employer attractiveness, "Business and Society" 2002, Vol. 41, No. 3, pp. 292-318.

[3] Bartunek J., Corporate scandals: how should Academy of Management members respond?, "Academy of Management Executive" 2002, Vol. 16, p. 138.

[4] Behrend T.S., Baker B.A. and Thompson L.F., Effects of pro-environmental recruiting messages: the role of organizational reputation, "Journal of Business Psychology" 2009, Vol. 23, pp. 341-350.

[5] Chen P., Choi Y., Generational differences in work values: a study of hospitality management, "International Journal of Contemporary Hospitality Management" 2008, (20), No. 6, pp. 595-615.

[6] Christensen L.J., Pierce E., Hartman L.P., Hoffman W.M., Carrier J., Ethics, CSR, and sustainability education in the Financial Times top 50 global business schools: baseline data and future research directions, "Journal of Business Ethics" 2007, Vol. 73 No. 4, pp. 347-368.

[7] Dolan S.L, Garcia S., Richley B., Managing by Values: A Corporate Guide to Living, being Alive and Making a Living in the 21st Century', Palgrave-Macmillan, London 2006.

[8] Dolan S.L., Richley B., Management by values (MBV): a new philosophy to absorb the complexity of managing organization in a new economic order [in:] Handbook of Business Strategy, ed. P. Coats, 2005.

[9] Ducassy I., Does Corporate Social Responsibility Pay Off in Times of Crisis? An Alternate Perspective on the Relationship between Financial and Corporate Social Performance. Corporate Social Responsibility and Environmental Management Corp. Soc. Responsib. Environ. Mgmt. 2012, pp. 157-167.

[10] Evans W.R. and Davis D.D., An examination of perceived corporate citizenship, job applicant attraction and CSR work role definition, „Business and Society“ 2011, Vol. 50 No. 3, pp. 456-480.

[11] Garcia S. and Dolan S.L., La direccio 'n por valores, McGraw-Hill, Madrid 2003.

[12] Geryk M., Społeczna odpowiedzialność uczelni, Szkoła Główna Handlowa w Warszawie, Warszawa 2012.

[13] Gentile M., Business schools: a failing grade on ethics, "Business Week" 2009, 5 February, available at: www.businessweek.com/bschools/content/feb2009/bs2009025_1294 77.htm (accessed 25 January 2010).

[14] Haniffa R., Ethics are needed in the boardroom, "Financial Times" 2009, November 29, available at: www.ft.com/cms/s/4230ad3e-db4f-11de-9023-00144feabdc0.html (accessed 25 January 2010).

[15] Jain P., Datta S.K., Roy A., Awareness and attitude towards corporate social responsibility, "International Journal of Law and Management" 2014, Vol. 56 Iss. 3 pp. 231-246, http://dx.doi.org/10.1108/IJLMA-05-2012-0012

[16] Kolondinsky R.W., Madden T.M., Zisk D.S. and Henkel E.T., Attitudes about corporate social responsibility: business student predictors, "Journal of Business Ethics" 2010, (91), pp. 167-181

[17] Kumar B.N. and Steinmann H. (Eds), Ethics in International Management, de Gruyter, New York 1998.

[18] Lamoreaux M.G. and Bonner P., Preparing for the next opportunity, "Journal of Accountancy" 2009, (208) No. 5, pp. 28-31.

[19] Nicolescu C., Corporate Social Responsibility in the Romanian Higher Education, Open Society Institute, Romania 2006. 
[20] Orr D., The Nature of Design, Oxford University Press, New York 2002.

[21] Owen D., CSR after Enron: a role for the academic accounting profession?, "European Accounting Review" 2007, (14), No. 2, pp. 395-404.

[22] Persons O., Incorporating Corporate Social Responsibility and Sustainability Into a Business Course: A Shared Experience, „Journal of Education for Business“ 2012, (87), pp. 63-72.

[23] Pesonen H., Challenges of integrating environmental sustainability issues into business school curriculum: a case study from the university of Jyva skyla, Finland, "Journal of Management Education" 2003, Vol. 27, No. 2, pp. 151-171.

[24] Prest M. (2009, December 3), Critics believe that MBA programmes need reform - but alumni don't agree. Retrieved June 25, 2015, from http://www.independent.co.uk/student /postgraduate/mbas-guide/critics-believe-that-mba-programmes-need-reform--ndash-butalumni-dont-agree-1832598.html

[25] Prosser M. \& Triggler K., Understanding Learning and Teaching. The experience in higher education University Press ed., Milton Keynes 1999.

[26] The more things change... (2009, June 4), Retrieved June 24, 2015, from http://www.economist.com/node/12762453

[27] Twenge J.M., Campbell S.M., Generational differences in psychological traits and their impact on the workplace, "Journal of Managerial Psychology" 2008, (23), pp. 862-877.

[28] Van Baalen P.J., Moratis, L.T., Management Education in the Network Economy: Its Context, Content, and Organization, Kluwer Academic Publishers, Dordrecht 2001.

[29] Young S., Nagpal S., Meeting the growing demand for sustainability-focused management education: a case study of a PRME academic institution, "Higher Education Research \& Development" 2013, Vol. 32, No. 3, pp. 493-506.

\section{EKSPLORACJA WARTOŚCI I POSTAW SPOLECZNIE ODPOWIEDZIAL- NYCH WŚRÓD STUDENTÓW SGH CEMS}

Celem niniejszego artykułu jest zbadanie wartości i postaw CSR wśród studentów CEMS SGH w Polsce. CEMS - światowy sojusz edukacji zarządzania jest stowarzyszeniem najlepszych uniwersytetów na całym świecie. Sojusz skupia 29 znanych uniwersytetów partnerskich, wśród grona prominentnych uczelni znajdują są: Szkoła Główna Handlowa w Polsce, Uniwersytet Ekonomiczny w Czechach lub ESADE w Hiszpanii. Studenci są traktowani jako przyszli menedżerowie a ich postrzeganie CSRu jest uważane za ważne dla organizacji biznesowych. Sektor edukacji jest postrzegany jako odgrywający kluczową rolę w przygotowaniu kolejnych pokoleń przyszłych liderów poprzez włączenie CSRu do programów nauczania czy programów badawczych. Badanie oferuje unikalny wgląd co do postaw CSRowych studentów w kontekście odpowiedzi na pytanie, w jakim stopniu edukacja studentów CEMS kształtuje wartości studentów. Badanie zostało przeprowadzone za pomocą ankiety online. Wartości CSR zostały zbadane w kontekście hipotetycznego scenariusza w poszukiwaniu pracy. Podczas gdy większość studentów oceniło wartości CSR wysoko w scenariuszu wyboru pracy, to w sytuacji zaoferowania wysokich benefitów i niskiej aktywności CSRowej firm studenci byli skłonni pójść na kompromis. Wyniki badań pozwolą na opracowanie skutecznych programów biznesowych, które kształtują społeczne zachowania odpowiedzialności przyszłych pokoleń menedżerów i liderów. $\mathrm{W}$ artykule wykorzystane dane $\mathrm{z}$ badań $\mathrm{z}$ małej próby studentów zarządzania na ograniczonym obszarze geograficznym, którym jest Polska. Stąd niemożliwe jest uogólnianie wyników do większej, bardziej reprezentatywnej populacji.

Słowa kluczowe: społeczna odpowiedzialność biznesu, edukacja CEMS, edukacja biznesowa, wartości, stosunek do społecznej odpowiedzialności biznesu

DOI: 10.7862/rz.2016.mmr.33 
Exploring values and attitudes towards CSR...

Tekst złożono w redakcji: kwiecień 2016

Przyjęto do druku: sierpień 2016 